Article

\title{
Suffruyabiosides A and B, Two New Monoterpene Diglycosides from Moutan Cortex
}

\author{
Rie Furuya, Honghai Hu, Zhenya Zhang and Hideyuki Shigemori * \\ Graduate School of Life and Environmental Sciences, University of Tsukuba, Tsukuba, Ibaraki, \\ 305-8572, Japan
}

* Author to whom correspondence should be addressed; E-Mail: hshige@agbi.tsukuba.ac.jp; Tel./Fax: +81-29-853-8572.

Received: 14 April 2012; in revised form: 16 April 2012 / Accepted: 16 April 2012 /

Published: 30 April 2012

\begin{abstract}
Two new monoterpene diglycosides, suffruyabiosides A (1) and B (2), and seven known compounds 3-9 were isolated from Moutan Cortex (root cortex of Paeonia suffruticosa Andrews). The structures were elucidated on the basis of 2D NMR spectral data. Suffruyabiosides A (1) and B (2) are rare monoterpene diglycosides, including a cellobiose in the molecules. Salicylpaeoniflorin (4) had a antiproliferation effect similar to paeoniflorin (3) on human lung adenocarcinoma epitherial A549 cells. Galloylpaeoniflorin (8) and salicylpaeoniflorin (4) revealed a more pronounced radical scavenging effect than $\alpha$-tocopherol (positive control). An increase in the number of phenolic hydroxyl groups produced a more effective radical scavenging effect $[8>$ mudanpioside E (6) $>$ oxypaeoniflorin (5)]. Comparison of the effects of $\mathbf{4}$ and $\mathbf{5}$ showed that $o$-substitution with a phenolic hydroxyl group was more effective than $p$-substitution. The results suggest that salicylpaeoniflorin (4) may be useful as a cytotoxic and a radical scavenging agent.
\end{abstract}

Keywords: monoterpene diglycoside; suffruyabiosides $\mathrm{A}$ and $\mathrm{B}$; human lung adenocarcinoma epitherial A549 cells; radical scavenging effect

\section{Introduction}

Moutan Cortex (root cortex of Paeonia suffruticosa Andrews) is one of the most important natural medicines in China, Korea, and Japan. The main production places of Moutan Cortex are Anhui, Sichuan, Gansu, Shaanxi, Hubei, Hunan, Shandong, Guizhou and other places in China. It is clinically 
used for its analgesic and anti-inflammatory properties, as well as a remedy for female genital diseases [1-4]. Moreover, the monoterpene glycosides isolated from Moutan Cortex are known for their radical scavenging effect [5]. In a recent study, paeoniflorin (3) exhibited antiproliferative activity against human lung adenocarcinoma epithelial A549 cells by arresting cell cycle progression in the $\mathrm{G}_{0} / \mathrm{G}_{1}$ phase and inducing apotosis [6]. However, the structure-activity relationships of the related monoterpene glycosides, including paeoniflorin (3), have not been studied in A549 cells. In this study, we isolated two new monoterpene diglycosides, suffruyabiosides A (1) and B (2), and known compounds 3-9 from Moutan Cortex. In addition, we examined the structure-activity relationships of cytotoxic activity on A549 cell and radical scavenging effect of compounds 1-9.

\section{Results and Discussion}

The EtOH extract of Moutan Cortex $\left(1.0 \mathrm{~kg}\right.$ ) was partitioned between EtOAc and $\mathrm{H}_{2} \mathrm{O}$, and then the $\mathrm{H}_{2} \mathrm{O}$-layer was partitioned with $n$ - $\mathrm{BuOH}$. The $n$-BuOH layer was separated by column chromatography on silica gel and ODS, and using HPLC to give two new monoterpene diglycosides, suffruyabiosides A (1, 0.00028\%) and B (2, 0.00013\%), together with seven known compounds 3-9. The known compounds 3-9 were identified as paeoniflorin (3) [3], salicylpaeoniflorin (4) [7], oxypaeoniflorin (5) [8,9], mudanpioside E (6) [10], mudanpioside D (7) [10], galloylpaeoniflorin (8) [2,9], and mudanpioside I (9) [11].

The molecular formula of suffruyabioside A (1) was assigned as $\mathrm{C}_{36} \mathrm{H}_{42} \mathrm{O}_{18}$ by HRESIMS $[\mathrm{m} / \mathrm{z}$ $785.2212(\mathrm{M}+\mathrm{Na})^{+}, \Delta-5.7 \mathrm{mmu}$. The IR spectrum indicated the presence of hydroxyl $\left(3412 \mathrm{~cm}^{-1}\right)$ and ester $\left(1729 \mathrm{~cm}^{-1}\right)$ moieties. The ${ }^{1} \mathrm{H}-$ and ${ }^{13} \mathrm{C}-\mathrm{NMR}$ spectra of $\mathbf{1}$ (Table 1) revealed signals assignable to a monoterpene pinane type skeleton similar to that of paeoniflorin (3) [12] with signals for three methylenes at $\delta_{\mathrm{H}} 2.21(1 \mathrm{H}, \mathrm{d}, J=13.0 \mathrm{~Hz}, \mathrm{H}-3), 1.73(1 \mathrm{H}, \mathrm{d}, J=13.0 \mathrm{~Hz}, \mathrm{H}-3), 1.73(1 \mathrm{H}, \mathrm{brd}$, $J=12.3 \mathrm{~Hz}, \mathrm{H}-7), 2.50(1 \mathrm{H}, \mathrm{m}, \mathrm{H}-7)$, and $4.87(2 \mathrm{H}, \mathrm{s}, \mathrm{H}-8)$, two methines at $\delta_{\mathrm{H}} 2.52(1 \mathrm{H}, \mathrm{m}, \mathrm{H}-5)$ and $5.40(1 \mathrm{H}, \mathrm{s}, \mathrm{H}-9)$, and one methyl at $\delta_{\mathrm{H}} 1.25(3 \mathrm{H}, \mathrm{s}, \mathrm{H}-10)$. HMBC correlations (Table 1, Figures 1 and 2) of H-5, H-7, H-8, H-9, and H-10 to C-1 ( $\left.\delta_{\mathrm{C}} 90.1\right), \mathrm{H}-7, \mathrm{H}-9$, and H-10 to C-2 $\left(\delta_{\mathrm{C}} 88.8\right), \mathrm{H}-10$ to C-3 $\left(\delta_{\mathrm{C}} 44.7\right), \mathrm{H}-3, \mathrm{H}-5$, and H-7 to C-4 $\left(\delta_{\mathrm{C}} 106.1\right), \mathrm{H}-3$ to C-5 $\left(\delta_{\mathrm{C}} 41.1\right), \mathrm{H}-8$ to C-6 $\left(\delta_{\mathrm{C}} 72.5\right), \mathrm{H}-5$ to C-7 $\left(\delta_{\mathrm{C}} 27.1\right)$, and $\mathrm{H}-8$ to $\mathrm{C}-9\left(\delta_{\mathrm{C}} 103.0\right)$ revealed the presence of a pinane type skeleton. The ${ }^{1} \mathrm{H}-{ }^{1} \mathrm{H}$ COSY connectivities of H-1"' to H-2"', H-5"' to H-6"', H-1"'" to H-2"'", and H-4"' to H-6"'" and HMBC correlations of H-2"' to C-4"' $\left(\delta_{\mathrm{C}} 82.1\right), \mathrm{H}-4$ "' to C-2"' $\left(\delta_{\mathrm{C}} 75.4\right), \mathrm{H}-5$ "' to C-3"' $\left(\delta_{\mathrm{C}} 78.7\right), \mathrm{H}-1$ "', $\mathrm{H}-4$ "'", and $\mathrm{H}-5$ "" to C-3"'" ( $\left.\delta_{\mathrm{C}} 72.4\right)$, and H-2"" and H-6"" to C-4"" $\left(\delta_{\mathrm{C}} 74.7\right)$ implied the presence of two sugar moieties. NOESY correlations of H-1"' to H-3"', H-1"' to H-5"', H-1"' to H-3"', H-1"' to H-5"', and H-2"'" to H-4"'" and two anomeric proton signals of H-1"' and H-1"'" observed a doublet at $\delta_{\mathrm{H}} 4.64$ $(1 \mathrm{H}, J=7.8 \mathrm{~Hz})$ and $4.44(1 \mathrm{H}, J=7.8 \mathrm{~Hz})$, suggesting the presence of two $\beta$-glucose moieties. Moreover the presence of benzoyl and $p$-hydroxybenzoyl groups was revealed by the ${ }^{1} \mathrm{H}-{ }^{1} \mathrm{H}$ COSY connectivities of H-2' to H-6', H-2" to H-3", and H-5" to H-6" and HMBC correlations of H-2' and H-6' to C-4' $\left(\delta_{\mathrm{C}} 135.3\right)$ and C-7' $\left(\delta_{\mathrm{C}} 168.3\right), \mathrm{H}-3$ " and H-5" to C-1" $\left(\delta_{\mathrm{C}} 120.0\right)$, and H-2" and H-6" to C-7" $\left(\delta_{\mathrm{C}} 168.8\right)$ and C-4" $\left(\delta_{\mathrm{C}} 163.6\right)$. HMBC correlations of H-8 $\left(\delta_{\mathrm{H}} 4.87\right)$ to C-7', H-4"' $\left(\delta_{\mathrm{H}} 3.64\right)$ to C-1"'" $\left(\delta_{\mathrm{C}} 105.7\right)$, and H-6"' $\left(\delta_{\mathrm{H}} 4.86\right)$ to C-7" $\left(\delta_{\mathrm{C}} 168.8\right)$ revealed that the benzoyl group was attached to $C-8\left(\delta_{C} 63.8\right)$ by the ester linkage, the first sugar was linked to $C-1$ "' $\left(\delta_{C} 100.6\right)$ with the other sugar 
attached to C-4"' $\left(\delta_{\mathrm{C}} 82.1\right)$ by ether linkages, and the $p$-hydroxybenzoyl group was connected to C-6"'" $\left(\delta_{\mathrm{C}} 65.4\right)$ of the other sugar through an ester linkage.

Table 1. ${ }^{13} \mathrm{C}$ - and ${ }^{1} \mathrm{H}-\mathrm{NMR}$ data of suffruyabiosides $\mathrm{A}(\mathbf{1})$ and $\mathrm{B}(\mathbf{2})$ in $\mathrm{CD}_{3} \mathrm{OD}$.

\begin{tabular}{|c|c|c|c|c|c|c|}
\hline & \multicolumn{3}{|c|}{ Suffruyabioside A (1) } & \multicolumn{3}{|c|}{ Suffruyabioside B (2) } \\
\hline & $\boldsymbol{\delta}_{\mathrm{C}}$ & $\delta_{\mathrm{H}}, J$ in $\mathbf{H z}$ & HMBC $^{a}$ & $\boldsymbol{\delta}_{\mathrm{C}}$ & $\delta_{\mathrm{H}}, J$ in $\mathrm{Hz}$ & HMBC $^{a}$ \\
\hline 1 & $90.1, \mathrm{C}$ & - & & $90.1, \mathrm{C}$ & - & \\
\hline 2 & $88.8, \mathrm{C}$ & - & & $87.8, \mathrm{C}$ & - & \\
\hline 3 & $44.7, \mathrm{CH}_{2}$ & $\begin{array}{l}1.73, \mathrm{~d}, 13.0 \\
2.21, \mathrm{~d}, 13.0\end{array}$ & 4,5 & $41.4, \mathrm{CH}_{2}$ & $\begin{array}{l}1.76, \mathrm{~d}, 13.9 \\
2.18, \mathrm{~d}, 13.9\end{array}$ & 2,5 \\
\hline 4 & 106.1, C & - & & 104.0, C & - & \\
\hline 5 & $41.1, \mathrm{CH}$ & $2.52, \mathrm{~m}$ & $1,4,7$ & $40.7, \mathrm{CH}$ & $2.56, \mathrm{~m}$ & 3,7 \\
\hline 6 & $72.5, \mathrm{C}$ & - & & $72.5, \mathrm{C}$ & - & \\
\hline 7 & 27.1, $\mathrm{CH}_{2}$ & $\begin{array}{l}1.73, \mathrm{bd}, 12.3 \\
2.50, \mathrm{~m}\end{array}$ & $1,2,4$ & $24.2, \mathrm{CH}_{2}$ & $\begin{array}{l}1.67, \mathrm{~d}, 9.5 \\
2.56, \mathrm{~m}\end{array}$ & $1,2,5$ \\
\hline 8 & $63.8, \mathrm{CH}_{2}$ & $4.87, \mathrm{~s}$ & $1,6,9,7^{\prime}$ & $62.8, \mathrm{CH}_{2}$ & $4.80, \mathrm{~s}$ & $9,7^{\prime}$ \\
\hline 9 & 103.0, $\mathrm{CH}$ & $5.40, \mathrm{~s}$ & 1,2 & $102.9, \mathrm{CH}$ & $5.50, \mathrm{~s}$ & 2 \\
\hline 10 & $22.5, \mathrm{CH}_{3}$ & $1.25, \mathrm{~s}$ & $1,2,3$ & $20.4, \mathrm{CH}_{3}$ & $1.22, \mathrm{~s}$ & $1,2,3$ \\
\hline $1^{\prime}$ & $131.1, \mathrm{C}$ & - & & $132.1, \mathrm{C}$ & - & \\
\hline $2^{\prime}$ & $130.7, \mathrm{CH}$ & $8.08, \mathrm{dt}, 7.8,1.2$ & $3^{\prime}, 4^{\prime}, 6^{\prime}, 7^{\prime}$ & $131.5, \mathrm{CH}$ & $8.09, \mathrm{dt}, 7.6,1.4$ & $1^{\prime}, 3^{\prime}, 4^{\prime}, 7^{\prime}$ \\
\hline $3^{\prime}$ & $130.6, \mathrm{CH}$ & $7.53, \mathrm{t}, 7.8$ & $1^{\prime}, 2^{\prime}, 5^{\prime}$ & $130.6, \mathrm{CH}$ & $7.54, t, 7.6$ & $2^{\prime}, 4^{\prime}$ \\
\hline $4^{\prime}$ & $135.3, \mathrm{CH}$ & $7.64, \mathrm{tt}, 7.4,1.2$ & $2^{\prime}, 3^{\prime}, 5^{\prime}, 6^{\prime}$ & $135.3, \mathrm{CH}$ & $7.66, \mathrm{tt}, 7.6,1.4$ & $3^{\prime}, 5^{\prime}$ \\
\hline $5^{\prime}$ & $130.6, \mathrm{CH}$ & $7.53, t, 7.8$ & $1^{\prime}, 2^{\prime}, 3^{\prime}$ & $130.6, \mathrm{CH}$ & $7.54, \mathrm{t}, 7.6$ & $4^{\prime}, 6^{\prime}$ \\
\hline $6^{\prime}$ & $130.7, \mathrm{CH}$ & $8.08, \mathrm{dt}, 7.8,1.2$ & $2^{\prime}, 3^{\prime}, 4^{\prime}, 7^{\prime}$ & $131.5, \mathrm{CH}$ & $8.09, \mathrm{dt}, 7.6,1.4$ & $1^{\prime}, 4^{\prime}, 5^{\prime}, 7^{\prime}$ \\
\hline $7^{\prime}$ & $168.3, \mathrm{C}$ & - & & $168.3, \mathrm{C}$ & - & \\
\hline $1 "$ & $120.0, \mathrm{C}$ & - & & $132.0, \mathrm{C}$ & - & \\
\hline $2 "$ & $133.8, \mathrm{CH}$ & $7.93, \mathrm{dd}, 8.8,1.9$ & 4", 6", 7" & $131.4, \mathrm{CH}$ & $8.07, \mathrm{dt}, 8.3,1.3$ & 1", 3", 4", 7" \\
\hline $3 "$ & $112.0, \mathrm{CH}$ & $6.86, \mathrm{dd}, 8.8,1.9$ & $1^{\prime \prime}, 5^{\prime \prime}$ & $130.4, \mathrm{CH}$ & $7.51, \mathrm{t}, 8.3$ & 2", 4" \\
\hline $4 "$ & $163.6, \mathrm{C}$ & - & & 135.2, CH & $7.65, \mathrm{tt}, 8.3,1.3$ & 3", 5" \\
\hline $5^{\prime \prime}$ & $112.0, \mathrm{CH}$ & $6.86, \mathrm{dd}, 8.8,1.9$ & 1", 3" & $130.4, \mathrm{CH}$ & $7.51, t, 8.3$ & 4", 6" \\
\hline $6 "$ & $133.8, \mathrm{CH}$ & $7.93, \mathrm{dd}, 8.8,1.9$ & 2", 4", 7" & $131.4, \mathrm{CH}$ & $8.07, \mathrm{dt}, 8.3,1.3$ & 1", 4", 5", 7" \\
\hline $7^{\prime \prime}$ & $168.8, \mathrm{C}$ & - & & $168.8, \mathrm{C}$ & - & \\
\hline $1 " '$ & $100.6, \mathrm{CH}$ & $4.64, \mathrm{~d}, 7.8$ & $1,5^{\prime \prime \prime}$ & 100.6, CH & $4.65, d, 7.8$ & $1,5^{\prime \prime}$ \\
\hline $2 " '$ & $75.4, \mathrm{CH}$ & $3.34, \mathrm{~m}$ & 4"' & $75.5, \mathrm{CH}$ & $3.35, \mathrm{~m}$ & 4"' \\
\hline 3"' & $78.7, \mathrm{CH}$ & $3.35, \mathrm{~m}$ & $1 " ', 5 " '$ & $79.1, \mathrm{CH}$ & $3.30, \mathrm{~m}$ & $1 " ', 5 " '$ \\
\hline 4"' & $82.1, \mathrm{CH}$ & $3.64, \mathrm{~m}$ & 2"', $1 " "$ & $82.2, \mathrm{CH}$ & $3.64, \mathrm{~m}$ & 2"', $1 " '$ \\
\hline $5 " '$ & 77.1, CH & $3.39, \mathrm{~m}$ & $3^{\prime \prime \prime}$ & $77.1, \mathrm{CH}$ & $3.39, \mathrm{~m}$ & $3^{\prime \prime \prime}$ \\
\hline 6"' & $63.3, \mathrm{CH}_{2}$ & $3.69, \mathrm{dd}, 11.9,5.7$ & $5^{\prime \prime \prime}$ & $63.3, \mathrm{CH}_{2}$ & $3.70, \mathrm{dd}, 12.0,6.3$ & $5^{\prime \prime \prime}$ \\
\hline & & $3.93, \mathrm{dd}, 11.9,2.0$ & $5^{\prime \prime \prime}$ & & $3.93, \mathrm{dd}, 12.0,2.0$ & 4"' \\
\hline $1 " "$ & $105.7, \mathrm{CH}$ & $4.44, \mathrm{~d}, 7.8$ & $3^{\prime \prime \prime}$ & 105.7, CH & $4.44, d, 7.8$ & $3^{\prime \prime \prime}$ \\
\hline 2"'" & 75.6, CH & $3.38, \mathrm{~m}$ & 1"', 4"'" & $75.6, \mathrm{CH}$ & $3.40, \mathrm{~m}$ & $4 " "$ \\
\hline 3"' & $72.4, \mathrm{CH}$ & $3.33, \mathrm{~m}$ & 1"', $5^{\prime \prime \prime}$ & $72.8, \mathrm{CH}$ & $3.30, \mathrm{~m}$ & 1"', 5 "'" \\
\hline 4"'" & 74.7, $\mathrm{CH}$ & $3.68, \mathrm{~m}$ & 2"'", 3"'" & $74.7, \mathrm{CH}$ & $3.60, \mathrm{~m}$ & 2"'", 3"'" \\
\hline 5"' & $78.7, \mathrm{CH}$ & $3.86, \mathrm{~m}$ & $3 " \prime \prime$ & $78.7, \mathrm{CH}$ & $3.81, \mathrm{~m}$ & $3 " \prime$ \\
\hline 6"" & $65.4, \mathrm{CH}_{2}$ & $4.65, \mathrm{dd}, 12.8,5.1$ & & $65.4, \mathrm{CH}_{2}$ & $4.66, \mathrm{dd}, 11.9,3.8$ & 7", 4"" \\
\hline & & $4.86, \mathrm{dd}, 12.8,2.0$ & 7", 4"'" & & $4.86, \mathrm{dd}, 11.9,2.0$ & 7" \\
\hline
\end{tabular}

${ }^{a} \mathrm{HMBC}$ correlations are from carbon stated to the indicated proton(s). 
Figure 1. Structures of suffuruyabiosides A (1) and B (2), and seven known compounds 3-9.
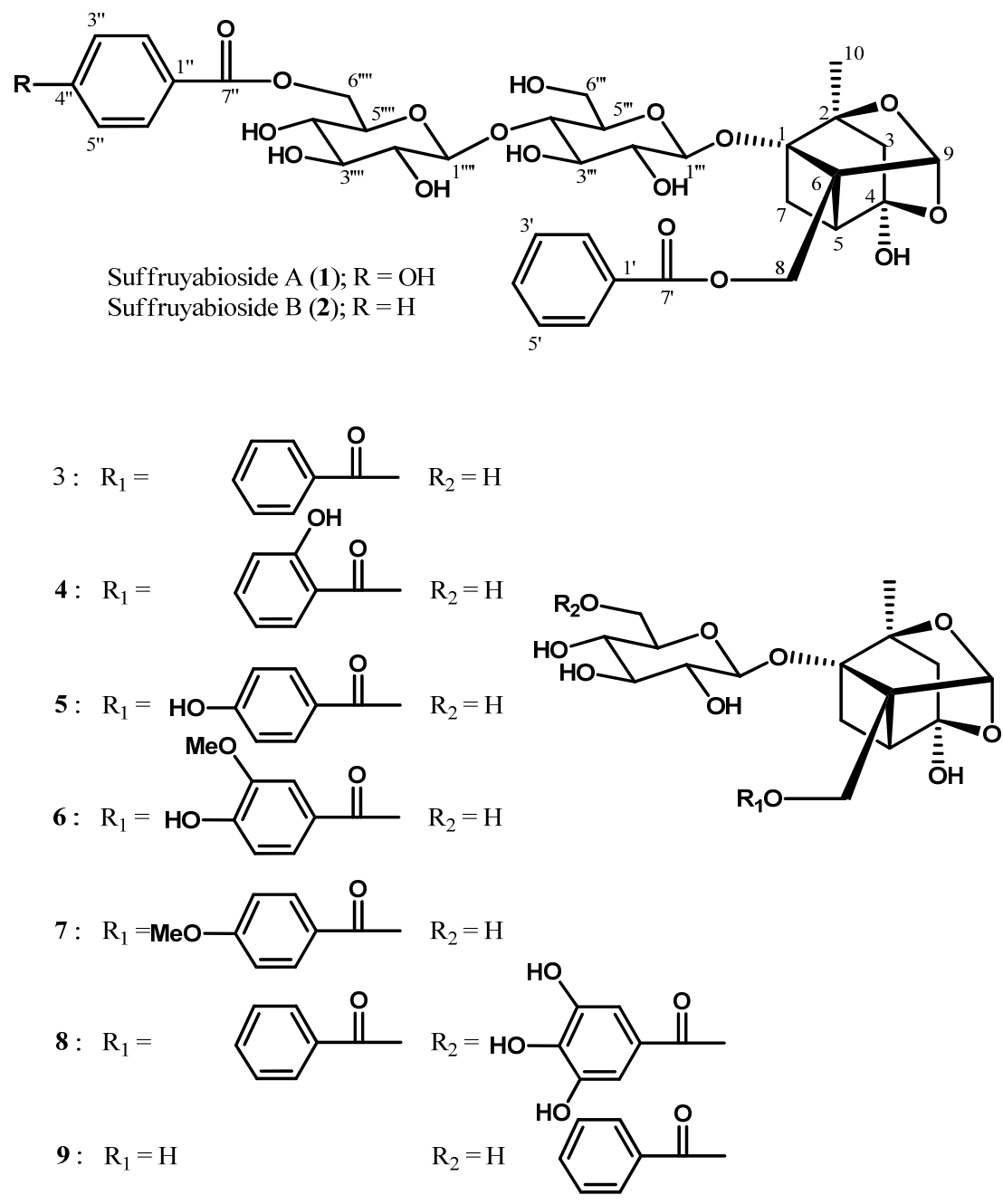

Figure 2. 2D NMR correlations of suffuruyabioside A (1).

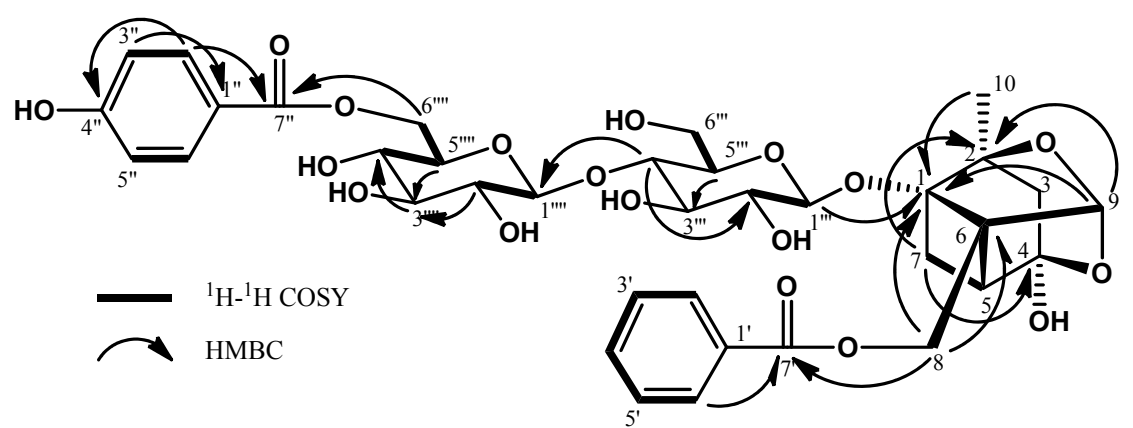

Suffruyabioside A (1)

The stereochemistry at various stereocenters of the monoterpene unit was assigned on the basis of similarity of the reported spectral data [13]. On the basis of these observations 1 was established as 6"'--O-p-hydroxybenzoyl-6"'-O- $\beta$-glucopyranosyl- paeoniflorin.

The ${ }^{1} \mathrm{H}$ and ${ }^{13} \mathrm{C}$-NMR spectra (Table 1) of suffruyabioside B (2) also resembled that of paeoniflorin (3), except for the additional appearance of sugar and benzoyl proton signals. The molecular formula was established as $\mathrm{C}_{36} \mathrm{H}_{42} \mathrm{O}_{17}$ by HRESIMS data $\left[\mathrm{m} / \mathrm{z} 769.2281(\mathrm{M}+\mathrm{Na})^{+}, \Delta-3.9 \mathrm{mmu}\right.$. Analysis of 
the IR spectrum of 2 suggested the presence of hydroxyl $\left(3388 \mathrm{~cm}^{-1}\right)$ and ester $\left(1711 \mathrm{~cm}^{-1}\right)$ groups in the molecule. The ${ }^{1} \mathrm{H}$ and ${ }^{13} \mathrm{C}-\mathrm{NMR}$ data indicated the presence of the same monoterpene pinane type skeleton as in 3 (Table 1). The two sugar NMR signals at H-1"' $\left(\delta_{\mathrm{H}} 4.65, J=7.8 \mathrm{~Hz} ; \delta_{\mathrm{C}} 100.6\right)$ and H-1"'" $\left(\delta_{\mathrm{H}} 4.44, J=7.8 \mathrm{~Hz} ; \delta_{\mathrm{C}} 105.7\right)$ and NOESY correlations of H-1"' to H-3"', H-1"' to H-5"', H-1"'" to $\mathrm{H}-3$ "', and H-1"' to H-5"' revealed the presence of two $\beta$-glucose moieties. Furthermore, analysis of the HMBC spectrum (Table 1) clearly indicated that the anomeric carbon C-1"" $\left(\delta_{\mathrm{C}} 105.7\right)$ was coupled with H-4"' $\left(\delta_{\mathrm{H}} 3.64\right)$ through the ether linkage. HMBC correlations of $\mathrm{H}_{2}-8\left(\delta_{\mathrm{H}} 4.80\right)$ to C-7' $\left(\delta_{\mathrm{C}} 168.3\right)$ indicated that the benzoyl group was attached to $\mathrm{C}-8\left(\delta_{\mathrm{C}} 62.8\right)$ of the aglycone by the ester linkage, while the other benzoyl group was connected to C-6"'" $\left(\delta_{\mathrm{C}} 65.4\right)$ of Glc2 by the ester linkage on the basis of HMBC correlation of H-6"" ( $\delta_{\mathrm{H}} 4.66$ and 4.86) to C-7" $\left(\delta_{\mathrm{C}} 168.8\right)$. Therefore, 2 was identified as 6"'"-O-benzoyl-6"' -O- $\beta$-glucopyranosylpaeoniflorin.

The cytotoxic activities of suffruyabiosides A (1) and B (2) and known compounds 3-9 against human lung adenocarcinoma epithelial A549 cells were assayed (Figure 3). Salicylpaeoniflorin (4) and paeoniflorin (3) showed moderate cytotoxicities (viabilities: $31 \%$ and 52\%, respectively), while other compounds including suffruyabiosides A (1) and B (2), showed very weak activities (viabilities: 63-100\%).

Figure 3. Antiproliferative effects of suffruyabiosides A (1) and B (2), and known compounds 3-9 for A549 cells. Cells were incubated with different concentration of each compound for $48 \mathrm{~h}$ in 96-well plates. Proliferation was measured by WST-8 Assay. Results are expressed as percentage cell proliferation relative to the control group. This assay was repeated two times. Data are the mean \pm SD of three determinations. ${ }^{*} *$ significant difference $(p<0.01) v s$. control cells. (Dunnett's test).

WST- 8 assay for A549 cells

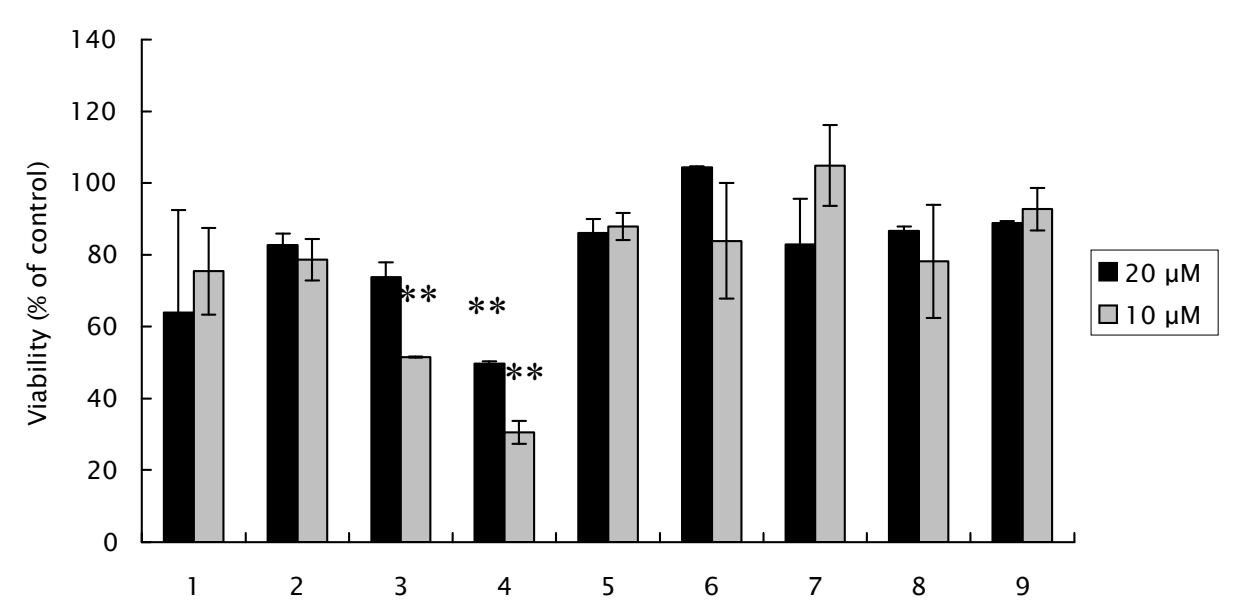

The structure-activity relationships for radical scavenging with isolated compounds 1-9 are shown in Figure 4. Galloylpaeoniflorin (8) was the most effective among the nine compounds 1-9. Galloylpaeoniflorin (8) and salicylpaeoniflorin (4) revealed a more pronounced radical scavenging effect than $\alpha$-tocopherol (positive control). Increase in the number of phenolic hydroxyl groups produced a more effective of radical scavenging effect $(8>6>5)$. Comparing the effect of 4 with 5 showed that $o$-substitution with a phenolic hydroxyl group was more effective than $p$-substitution. In 
addition, mudanpioside I (9) was more effective than paeoniflorin (3), indicating that a benzoyl group connected to a C- 6 of the $\beta$-glucose by the ester linkage was more effective for radical scavenging than a benzoyl group attached to the $\mathrm{C}-8$ monoterpene pinane type skeleton.

Figure 4. Radical scavenging effects of suffruyabiosides A (1) and B (2) and known compounds 3-9. After the incubation of the plate at $37{ }^{\circ} \mathrm{C}$ for $20 \mathrm{~min}$, read the absorbance at $450 \mathrm{~nm}$ using an ELISA reader. This assay was repeated two times. Data are the mean \pm SD of three determinations.

SOD assa!

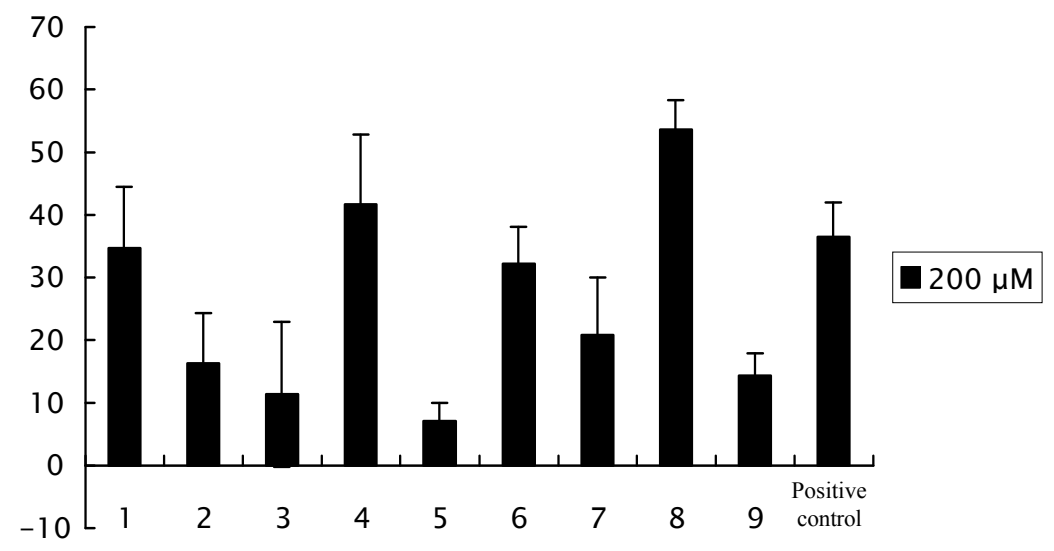

In conclusion, two new monoterpene glycosides, suffruyabiosides A (1) and B (2) were isolated from Moutan Cortex. It was the first reported as having a cellobiose in paeoniflorin related compounds [9]. Salicylpaeoniflorin (4) exhibited both cytotoxic activity against A549 cells and a radical scavenging effect in an SOD assay, suggesting that salicylpaeoniflorin (4) may be useful as a cytotoxic and a radical scavenging agent.

\section{Experimental}

\subsection{General}

Optical rotations were measured with a JASCO DIP-370 polarimeter. IR spectra were recorded on a JASCO FT/IR-300 spectrometer. ${ }^{1} \mathrm{H}-\mathrm{NMR}(500 \mathrm{MHz})$ and ${ }^{13} \mathrm{C}-\mathrm{NMR}(125 \mathrm{MHz})$ spectra were measured and recorded in $\mathrm{CD}_{3} \mathrm{OD}$ on a Bruker Avance 500 spectrometer. Chemical shift values $(\delta)$ were reported in parts per million (ppm) relative to $\mathrm{CD}_{3} \mathrm{OD}\left(\delta_{\mathrm{H}} 3.35, \delta_{\mathrm{C}} 49.8\right)$. HRESIMS were recorded on Waters Xevo Q-Tof.

\subsection{Plant Material}

Moutan Cortex (the roots cortex of Paeonia suffruticosa Andrews.) was purchased from Beijing Tong Ren Tang Group Co., Ltd. in November 2007, which was collected from Anhui Province in China and dried by sunlight. This sample was paeoniaceae plant peony root bark, and the root was removed the wooden heart, washed, sliced, and dried. A voucher specimen has been deposited at the Graduate School of Life and Environmental Sciences, University of Tsukuba, Tsukuba, Japan. 


\subsection{Extraction and Isolation}

Moutan Cortex $(1.0 \mathrm{~kg})$ was crushed with homogenizer and extracted three times with EtOH $(2 \mathrm{~L} \times 3)$ overnight at room temperature, followed by removal of solvent under reduced pressure, to yield a dried EtOH extract $(340 \mathrm{~g})$. The EtOH extract was dissolved in $\mathrm{H}_{2} \mathrm{O}(900 \mathrm{~mL})$ and extracted with EtOAc $(900 \mathrm{~mL} \times 3)$. The $\mathrm{H}_{2} \mathrm{O}$-soluble portion was partitioned between $n$-BuOH $(900 \mathrm{~mL} \times 3)$ and aqueous layers. The $n$ - $\mathrm{BuOH}$ layer $(16.4 \mathrm{~g})$ was chromatographed on a silica gel using $\mathrm{CHCl}_{3}-\mathrm{MeOH}-\mathrm{H}_{2} \mathrm{O}$ $(65: 25: 4 \rightarrow 5: 5: 1)$ to afford MC-BU-1 11. Further MC-BU-4 was separated using chromatograph on an ODS with $\mathrm{MeOH}-\mathrm{H}_{2} \mathrm{O}(1: 9 \rightarrow 3: 7 \rightarrow 1: 1)$, to give 8 fractions MC-BU-4-1 8. MC-BU-4-4 was subjected to passage over an ODS HPLC column (TSK-gel ODS-80Ts, TOSOH, $\phi 7.8 \times 300 \mathrm{~mm}$, $\mathrm{MeOH}-\mathrm{H}_{2} \mathrm{O}=20: 80 \rightarrow$ 100:0, $\left.1.0 \mathrm{~mL} / \mathrm{min}\right)$ to give oxypaeoniflorin $(\mathbf{5}, 25.3 \mathrm{mg})$. MC-BU-4-4-12 was further purified using an ODS HPLC column (TSK-gel ODS-80Ts, TOSOH, $\phi 4.6 \times 250 \mathrm{~mm}, \mathrm{MeOH}$ : $\left.\mathrm{H}_{2} \mathrm{O}=20: 80 \rightarrow 100: 0,1.0 \mathrm{~mL} / \mathrm{min}\right)$ to give mudanpioside $\mathrm{E}(6,1.4 \mathrm{mg})$. MC-BU-4-5 (548.5 mg) was subjected to passage over an ODS HPLC column (TSK-gel ODS-80Ts, TOSOH, $\phi 7.8 \times 300 \mathrm{~mm}$, $\left.\mathrm{MeOH}-\mathrm{H}_{2} \mathrm{O}=20: 80 \rightarrow 100: 0,1.0 \mathrm{~mL} / \mathrm{min}\right)$ to give paeoniflorin $(3,127.6 \mathrm{mg})$ and mudanpioside $\mathrm{D}(\mathbf{7}$, $0.9 \mathrm{mg}$ ). MC-BU-4-5-8 was further purified by an ODS HPLC column (TSK-gel ODS-80Ts, TOSOH, $\left.\phi 7.8 \times 300 \mathrm{~mm}, \mathrm{MeOH}-\mathrm{H}_{2} \mathrm{O}=30: 80 \rightarrow 100: 0,1.0 \mathrm{~mL} / \mathrm{min}\right)$ to give salicylpaeoniflorin $(4,2.6 \mathrm{mg})$. MC-BU-4-6 (79.2 mg) subjected to passage over an ODS HPLC column (TSK-gel ODS-80Ts, $\mathrm{TOSOH}, \phi 7.8 \times 300 \mathrm{~mm}, \mathrm{MeOH}-\mathrm{H}_{2} \mathrm{O}=35: 65 \rightarrow 100: 0,1.0 \mathrm{~mL} / \mathrm{min}$ ) to give 9 fractions MC-BU-4-6-1 9. MC-BU-4-6-6 and MC-BU-4-6-7 were purified to give galloylpaeoniflorin $(8,4.7 \mathrm{mg})$ and mudanpioside I (9,3.3 mg), respectively. MC-BU-4-6-8 was then purified by separation over an ODS HPLC column (TSK-gel ODS-80Ts, TOSOH, $\phi 4.6 \times 250 \mathrm{~mm}, \mathrm{MeOH}-\mathrm{H}_{2} \mathrm{O}=40: 60 \rightarrow$ 100:0, $0.8 \mathrm{~mL} / \mathrm{min})$ to give suffruyabioside A $(1,2.8 \mathrm{mg})$. MC-BU-4-6-9 further purified using an ODS HPLC column (TSK-gel ODS-80Ts, TOSOH, $\phi 4.6 \times 250 \mathrm{~mm}, \mathrm{MeOH}-\mathrm{H}_{2} \mathrm{O}=50: 50 \rightarrow$ 100:0, $1.0 \mathrm{~mL} / \mathrm{min})$ to give suffruyabioside $\mathrm{B}(2,1.3 \mathrm{mg})$.

Suffruyabioside A (1). Colorless amorphous solid; $[\alpha]_{\mathrm{D}}{ }^{27}-18.0(c=1.00, \mathrm{MeOH})$; IR $(\mathrm{KBr}) v_{\max } 3412$, 1729, 1525, 1404, and $1069 \mathrm{~cm}^{-1}$; UV (MeOH) $\lambda_{\max } \mathrm{nm}(\varepsilon) 206$ (26500), 226 (18400), and 258 (13700); ${ }^{1} \mathrm{H}$ and ${ }^{13} \mathrm{C}-\mathrm{NMR}$ see Table 1; ESIMS $m / z 785[\mathrm{M}+\mathrm{Na}]^{+}$; HRESIMS $m / z 785.2212[\mathrm{M}+\mathrm{Na}]^{+}$, calcd for $\mathrm{C}_{36} \mathrm{H}_{42} \mathrm{O}_{18} \mathrm{Na}, 785.2269$.

Suffruyabioside $B(2)$. Pale yellow amorphous solid; $[\alpha]_{\mathrm{D}}{ }^{28}-14.0(c=1.00, \mathrm{MeOH})$; IR $(\mathrm{KBr}) v_{\max }$ 3388, 1711, 1459, 1357, and $1078 \mathrm{~cm}^{-1}$; UV(MeOH) $\lambda_{\max } \mathrm{nm}(\varepsilon) 202$ (18700), 226 (26300), and 258 (4500); ${ }^{1} \mathrm{H}$ and ${ }^{13} \mathrm{C}-\mathrm{NMR}$ : see Table 1; ESIMS $m / z 769[\mathrm{M}+\mathrm{Na}]^{+}$; HRESIMS $m / z$ 769.2281 [M+Na $]^{+}$, calcd for $\mathrm{C}_{36} \mathrm{H}_{42} \mathrm{O}_{17} \mathrm{Na}, 769.2320$.

\subsection{Preparation of Paeoniflorin and Other Compounds}

Suffruyabiosides A (1) and B (2) and other seven known compounds 3-9 were dissolved in water and stored at $-30{ }^{\circ} \mathrm{C}$. For all cell proliferation assay, the final concentrations of the test compounds were prepared by diluting the stock with RPMI-1640. Control cultures also received the carrier solvent RPMI-1640. 


\subsection{Cell Culture}

Human lung adenocarcinoma epithelial A549 cells (ATCC CCL 185, RIKEN Cell Bank) was maintained in monolayer culture at $37{ }^{\circ} \mathrm{C}$ and $5 \% \mathrm{CO}_{2}$ in RPMI-1640 supplemented with $10 \%$ FBS, 100 units/mL penicillin $\mathrm{G}$ and $100 \mu \mathrm{g} / \mathrm{mL}$ streptomycin.

\subsection{Cell Proliferation Assay}

Inhibition of cell proliferation for A549 cell by suffruyabiosides A (1) and B (2) and other seven known compounds 3-9 was measured using the WST-8 assay. Briefly, cells were placed in 96-well culture plates $\left(1 \times 10^{4}\right.$ cells/well $)$. After $24 \mathrm{~h}$ incubation, cells were then incubated for $48 \mathrm{~h}$ in the presence or absence of compounds 1-9 (20 and $10 \mu \mathrm{M})$ dissolved in culture medium and an appropriate solvent. The WST-8 test solution $(10 \mu \mathrm{L})$ was added to each well. After $4 \mathrm{~h}$ incubation, absorbance was measured on ELISA reader (Microplate Reader Model 550, Bio-RAD) at the test wavelength of $450 \mathrm{~nm}$. RPMI-1640 supplemented with 10\% FBS was used as the negative control.

\subsection{Radical Scavenging Effect with SOD}

Suffruyabiosides A (1) and B (2) and other seven known compounds 3-9 were subjected to a superoxide dismutase (SOD) assay using the SOD Assay Kit-WST according to the technical manual. Briefly, in a 96-well plate, $20 \mu \mathrm{L}$ of sample solution was added to each sample and blank 2 well, and $20 \mu \mathrm{L}$ of double distilled water was added to each blank 1 and blank 3 well. Then $200 \mu \mathrm{L}$ of WST working solution was added to each well. After mixing, $20 \mu \mathrm{L}$ of dilution buffer was added to each blank 2 and blank 3 well, and $20 \mu \mathrm{L}$ of enzyme working solution $(15 \mu \mathrm{L}$ of enzyme mixted with 2.5 $\mu \mathrm{L}$ dilution buffer) was added to each sample and blank 1 well. The plate was incubated at $37{ }^{\circ} \mathrm{C}$ for $20 \mathrm{~min}$ and the O.D. was determined at $450 \mathrm{~nm}$ using an ELISA reader (Microplate Reader Model 550, Bio-RAD). The SOD-like activity was calculated by the following equation:

SOD activity (inhibition rate \%) $=\{[($ A blank 1-A blank 3$)-($ A sample-A blank 2$)] /$ (A blank 1-A blank 3) $\} \times 100$

where A blank 1, A blank 2, A blank 3, and A sample were the absorbance of blank 1, blank 2, blank 3, and the sample, respectively.

\section{Conclusions}

Two new monoterpene diglycosides, suffruyabiosides A (1) and B (2), and seven known compounds 3-9 were isolated from Moutan Cortex (root cortex of Paeonia suffruticosa Andrews). Suffruyabiosides A (1) and B (2) are rare monoterpene diglycosides, including a cellobiose in the molecules. Salicylpaeoniflorin (4) had a cytotoxic effect on human lung adenocarcinoma epitherial A549 cells and radical scavenging effect.

\section{Acknowledgement}

This work was partly supported by Grant-in-Aids for the Ministry of Education, Science, Sports, and Culture of Japan. 


\section{References and Notes}

1. Kostova, N.I.; Simeonov, F.M.; Todorova, I.D. A monoterpene glucoside from Paeonia peregrina roots. Phytochemistry 1998, 47, 1303-1307.

2. Yoshikawa, M.; Uchida, E.; Kawaguchi, A.; Kitagawa, I.; Yamahara, J. Galloyloxypaeoniflorin, suffruticosides A, B, C, and D, five new antioxidative glycosides, and suffruticoside E, A paeonol glycoside, from Chinese Moutan Cortex. Chem. Pharm. Bull. 1992, 40, 2248-2250.

3. Ding, H.Y.; Lin, H.C.; Teng, C.M.; Wu, Y.C. Phytochemical and pharmacological studies on Chinese Paeonia species. J. Chin. Chem. Soc. 2000, 47, 381-388.

4. Xu, S.J.; Yang, L.; Zeng, X.; Zhang, M.; Wang, Z.T. Characterization of compounds in the Chinese herbal drug Mu-Dan-Pi by liquid chromatography coupled to electrospray ionization mass spectrometry. Mass Spectrom. 2006, 20, 3275-3288.

5. Matsuda, H.; Ohta, T.; Kawaguchi, A.; Yoshioka, M. Bioactive constituents of chinese natural medicines. VI. Moutan cortex. (2): Structures and radical scavenging effects of suffruticosides A, B, C, D, and E and galloyl-oxypaeoniflorin. Chem. Pharm. Bull. 2001, 49, 69-72.

6. Hung, J.Y.; Yangm, C.J.; Tsai, Y.M.; Huang, H.W.; Huang, M.S. Antiproliferative activity of paeoniflorin is through cell cycle arrest and the Fas/Fas ligand-mediated apoptotic pathway in human non-small cell lung cancer A549 cells. Clin. Exper. Pharm. Physiol. 2008, 35, 141-147.

7. Okasaka, M.; Kashiwada, Y.; Kodzhimatov, K.O.; Ashurmetov, O.; Takaishi, Y. Monoterpene glycosides from Paeonia hybrida. Phytochemistry 2008, 69, 1767-1772.

8. Naheed, R.; Abdul, M.; Aziz-ur, R.; Zaheer, A.; Pir, M.; Sarfraz, A.N.; Juveria, S.; Choudhary, I.M. Lipoxygenase inhibiting and antioxidant oligostilbene and monoterpene galactoside from Paeonia emodi. Phytohemistry 2004, 65, 1129-1135.

9. Tanaka, T.; Kataoka, M.; Tsuboi, N.; Kouno, I. New monoterpene glycoside esters and phenolic constituents of Paeoniae Radix, and increase of water solubility of proanthocyanidins in the presence of paeoniflorin. Chem. Pharm. Bull. 2000, 48, 201-207.

10. Lin, H.C.; Ding, H.Y.; Wu, T.S.; Wu, P.L. Monoterpene glycosides from Paeonia suffruticosa. Phytochemistry 1996, 41, 237-242.

11. Ding, H.Y.; Wu, Y.C.; Lin, H.C.; Chan, Y.Y.; Wu, P.L.; Wu, T.S. Glycosides from Paeonia suffruticosa. Chem. Pharm. Bull. 1999, 47, 652-655.

12. Yamasaki, K.; Kaneda, M.; Tanaka, O. Carbon-13 NMR spectral assignments of paeoniflorin homologs with the aid of spin-lattice relaxation time. Tetrahedron Lett. 1976, 17, 3965-3968.

13. Kaneda, M.; Iitaka, Y.; Shibata, S. Chemical studies on the oriental plant drugs. XXXIII. Absolute structure of paeoniflorin, albiflorin, oxypaeoniflorin, and benzoylpaeoniflorin isolated from Chinese paeony root. Tetrahedron 1972, 28, 4309-4317.

Sample Availability: Samples of the compounds $\mathbf{3}$ and $\mathbf{5}$ are available from the authors.

(C) 2012 by the authors; licensee MDPI, Basel, Switzerland. This article is an open access article distributed under the terms and conditions of the Creative Commons Attribution license (http://creativecommons.org/licenses/by/3.0/). 